Full length Article

\title{
Labour market conditions and the corporate financing decision: A European analysis ${ }^{\text {h }}$
}

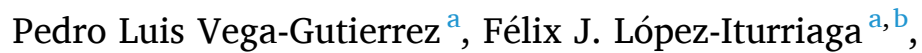 \\ Juan Antonio Rodriguez-Sanz ${ }^{a, *}$ \\ ${ }^{\text {a }}$ University of Valladolid, Department of Financial Economics and Accounting, Faculty of Economics, Avenida Valle de Esgueva, 6 - 47011, \\ Valladolid, Spain \\ ${ }^{\mathrm{b}}$ National Research University Higher School of Economics, ID Lab of Intangible-driven Economy, Perm, Russian Federation
}

\section{A R T I C L E I N F O}

\section{JEL classifications:}

G30

G32

D22

$\mathrm{C} 23$

Keywords:

Capital structure

Unemployment

Inflation

Labour market

Employees'rights

Wage rigidity

\begin{abstract}
A B S T R A C T
This study examines the influence of labour market conditions on corporate capital structure in a sample of 2892 firms from France, Germany, Italy, Spain, and the UK. After considering the effect of unemployment and inflation, we analyse the impact of two market imperfections: employees' rights and downward wage rigidity. Results indicate that financial leverage responds to changes in unemployment and inflation. We also find that the influence of employees' rights is non-linear, whereas the negative effect of downward wage rigidity is moderated by firms' market power. Taken together, our results show that corporate financial decisions are conditioned not only by firm-level issues but also by a country's labour market.
\end{abstract}

\section{Introduction}

Traditional financial theories have underestimated the effect of the macroeconomic environment on firms' capital structure (Cook and Tang, 2010; Daskalakis et al., 2017; Chang et al., 2019). In this study, we aim to fill this gap by focusing on one of the most important markets for firms: the labour market. At the firm level, previous research has analysed the relationship between firm leverage and labour demand (Funke et al., 1999; Basu, 2015) or employee treatment (Bae et al., 2011). Nevertheless, we still lack a unifying framework that evidences how labour market conditions might affect corporate capital structure. We therefore posit that capital structure theories must be extended to take account of the labour market features in which the firm operates (Aubert et al., 2017). In this way, we respond to the demands made in recent studies, such as Matsa (2018), calling for empirical analyses of how a company's workforce affects its corporate financing decision.

Among the diverse theories on capital structure, the trade-off theory offers one of the most widely known theoretical backgrounds

The authors are grateful to Philip Jaggs and two anonymous referees for suggestions and comments on previous versions of the paper. All the remaining errors are the authors' sole responsibility. This work was supported by the Spanish Ministry of Economy and Competitiveness [grant number ECO2017-84864-P].

* Corresponding author.

E-mail addresses: pedroluis.vega@uva.es (P.L. Vega-Gutierrez), flopez@eco.uva.es (F.J. López-Iturriaga), juanantonio.rodriguez@uva.es (J.A. Rodriguez-Sanz). 
on which our research can be based. According to this well-known theory, the optimal capital structure would balance the benefits related to corporate taxes that encourage the use of debt and the disadvantages associated to bankruptcy costs (Ardalan, 2017). In this theoretical framework, certain labour market issues might impact the indirect costs of financial distress that could affect companies' flexibility to adapt to the economic environment and, thus, their bankruptcy risk (Titman, 1984; Kahl et al., 2014; Serfling, 2016).

Our main purpose is to examine which labour market conditions might influence firms' financing decision. Consequently, we first explore the effect of two relevant macroeconomic variables related to the labour market: unemployment and inflation. Second, we analyse how labour market imperfections affect the financing decision and focus on employees' legal protection and downward wage rigidity.

Europe provides an appropriate setting for this analysis because of the different labour protection offered in civil law countries compared to common law countries (Botero et al., 2004). The European institutional framework was completed after World War II. In fact, by the 1980s, the debate between labour market regulations intensified due to the low unemployment rate in the USA which contrasted with the higher rate in European nations, who enforced more stringent labour regulations, more extensive collective bargaining, more powerful unions, and more generous unemployment insurance regimes (Hayter, 2011; Betcherman, 2014). There are significant differences in the labour market across Europe that should be kept in mind. For example, Lallement (2011) notes some similarities in the high level of employment protection and segmentation in France and Spain, whereas the German system is characterized by the ability to use internal mobility to reduce work time. Boeri (2011) even establishes some groups of countries based on the institutional characteristics of their labour markets. Mediterranean countries, like Italy and Spain, rely mostly on employment protection and offer relatively low unemployment benefits. In contrast, so-called traditional continental countries, like France and Germany, rely on unemployment benefits, whereas "Anglo-Saxon" countries can be characterized by weak unions, decentralized collective bargaining systems, and a stringent approach to employment protection. In turn, joint analysis of European firms might reveal the influence of different types of labour markets.

We study a sample of 2892 non-financial listed firms from five European Union countries (Germany, Spain, France, Italy, and the United Kingdom). We obtain three sets of results. First, we find that financial leverage is negatively related to the unemployment rate and positively related to the inflation rate. Second, our results suggest a non-linear relationship with employees' labour rights; positive for low levels of labour rights and negative for high levels. Third, we find a negative relationship with downward wage rigidity, with this effect being moderated by firms' market power.

This study contributes to previous literature on the corporate financing decision and goes a step further by exploring the relationship between capital structure and a country's labour conditions in two ways. First, we reconcile previous contradictory results about the effect of employees' rights on capital structure. By combining different theoretical approaches, we detect an inverted Ushaped relationship between employees' labour rights and leverage. We explain this relationship from an agency theory perspective in the case of direct rights, while the opportunity cost of leisure perspective provides the theoretical justification for the influence of indirect rights. Second, we address the question concerning how downward wage rigidity affects the corporate financing decision, to which very little attention has previously been paid. Wages stickiness theories allow us to explain this influence and to analyse the moderating role of market power from a microeconomic theory perspective. The results confirm that market labour conditions exert a decisive influence on firms' capital structure, thereby providing academia and managers with new insights into this relationship.

The rest of the paper is organized as follows. Section 2 reviews the theoretical foundations of the relationship between capital structure and labour market conditions and introduces the hypotheses to be tested. Section 3 describes the sample, variables, and research method. Section 4 presents and discusses the empirical results. Section 5 presents some robustness tests. Finally, in section 6 , the main conclusions of the study are summarized.

\section{Theoretical background and hypotheses development}

Three popular theories have largely contributed to explain firms' capital structure. The pecking order theory establishes that firms only issue debt when there is a deficit between internal funds and investment (Shyam-Sunder and Myers, 1999). The capital structure does not imply achieving an optimum, but rather meeting the firm's financial needs (Frank and Goyal, 2009). When obtaining new funds, firms face an asymmetric information problem between investors and managers, which forces firms to follow a pecking order: internally generated funds, debt and, finally, equity. The second theoretical approach is the market timing theory, which stresses the right moment of the equity market (market-timing), such that firms issue shares when their price is high and repurchase them when the price falls.

A complementary explanation is given by the trade-off theory. According to this theory, the optimal capital structure leads to a balance between the costs and benefits of debt (the static theory of trade-off). Later, this argument was reinforced with the idea that debt also disciplines managerial discretionary behaviour by reducing free cash flow, discouraging suboptimal investment policies, and limiting the consumption of perquisites (Jensen, 1986; Jensen and Meckling, 1976). However, debt can also increase the agency cost arising from conflicts between shareholders and debtholders, and high levels of leverage can lead to underinvestment problems (Barnea et al., 1985; Berger and Bonaccorsi di Patti, 2006; Myers, 1977; Myers and Majluf, 1984; Stulz, 1990). All these arguments suggest an optimum or target level of capital structure which the firm would reach in the absence of adjustment costs. Nevertheless, in the real world firms pursue this target over time, partially adjusting the leverage in each period (Flannery and Rangan, 2006). This partial-adjustment model allows the static trade-off theory to be transformed into a dynamic model, as we describe in the methodology section.

Our research is related to this extended trade-off theory in the sense that we analyse the relevance of certain indirect costs of financial distress, related to the labour market, that influence firms' leverage flexibility and bankruptcy risk (Kahl et al., 2014; Serfling, 
2016; Chen and Matousek, 2020). The literature has proposed three groups of financial distress indicators (Habib et al., 2020). The first is related to firms' characteristics, the second refers to corporate governance, and the last one includes some country factors such as labour market conditions. The following subsections provide a theoretical rationale together with some specific explanations about the effect of the labour market on capital structure in the context of European listed firms.

\subsection{Unemployment, inflation, and capital structure}

As shown by the Phillips curve, unemployment and inflation are two of the most relevant macroeconomic factors and are related to each other in the short-term (Phillips, 1958; Blanchard, 2017). However, despite the salient role of unemployment and inflation in the labour market, there is still no conclusive evidence regarding their influence on firms' financing decision (Camara, 2012; Mokhova and Zinecker, 2014). Akyol and Verwijmeren (2013) find a positive relationship between financial leverage and wages, and between wages and unemployment, both in the United States and in the Netherlands, whereas Mokhova and Zinecker (2014) conclude that this relationship can be either positive or negative for a sample from seven European countries.

During the expansive phase of the business cycle, the decreasing unemployment rate is likely to have a positive relationship with financial leverage for two reasons. First, higher employee consumption resulting from low unemployment improves firms' cash flows, thereby easing access to external funds (Mishkin, 2016). Second, employees require less additional compensation for the unemployment risk (Graham et al., 2016), which increases firms' financial performance and reduces bankruptcy costs. The opposite occurs in the contractive phase of the business cycle. Thus, we could expect a negative relationship between unemployment rates and financial leverage, such that we state our first hypothesis as follows:

H1. Unemployment is negatively related to corporate financial leverage.

As far as inflation is concerned, the evidence is not conclusive. Whereas some papers report that inflation does not exert a significant influence on leverage (Bastos et al., 2009; Daskalakis, 2017), other authors control for inflation when studying firms' debt ratios (Antoniou et al., 2008). Some authors have shown a positive relationship between leverage and inflation, although the significance depends on the model specifications (Hanousek and Shamshur, 2011; Zhou et al., 2016; Huong, 2018). In contrast, other papers report a negative relationship as a result of inflation uncertainty, which increases business risk (Aggarwal and Kyaw, 2006), or even a sign-changing relationship depending on the country analysed (Škuláňová, 2019).

During the expansive phase of the business cycle, inflation usually increases, which enhances firms' financial leverage for two reasons (Chang et al., 2019); firstly, because it alleviates pressure on real wages (Keynes, 1936; Olivera, 1964; Tobin, 1972; Akerlof et al., 1996; Elsby, 2009) and thus reduces operational leverage, and secondly because the real or current value of debt decreases. In the contractive phase, there is a deflationary climate that increases the pressure on real wages and on the real value of debt. This pressure hampers firms' leverage due to rising bankruptcy costs. Consequently, we state our second hypothesis as follows:

H2. The relationship between corporate leverage and inflation is positive.

\subsection{Labour market imperfections: employees' rights}

In addition to the above-mentioned factors, there are also some imperfections in the labour market that can cause serious adjustment problems between labour supply and demand and which, in turn, can have a significant impact on firms' financing decision. We focus on two of these imperfections: employees' legal protection and downward wage rigidity.

As regards employees' rights, we can distinguish between direct rights (i.e., those that increase employee power during negotiations) and indirect rights (those that enhance employee power not to reach an agreement and to remain unemployed). In any case, the sign of the final impact on capital structure is unclear since there are arguments to support both a positive and a negative relationship with corporate financial leverage.

Direct labour rights can be positively related to financial leverage for two main reasons. First, when employees are endowed with more legal protection and feel safer, they might reduce their demands on the firm, and firms might take advantage of this lower pressure in order to increase financial leverage. The literature has shown that higher firing costs reduce the dismissal risk and the premium wage that employees demand to make up for it, allowing higher leverage (Agrawal and Matsa, 2013; Serfling, 2016). Additionally, debt can be used as a strategic tool to strengthen firms' bargaining power with employees and to fight their demands (Hennessy and Livdan, 2009; Serfling, 2013; Matsa, 2010; 2018; Ellul and Pagano, 2019).

There may also be a positive relationship between indirect labour rights and financial leverage. When the perceived risk of unemployment is high, workers will demand better salary conditions, which increases the operational risk and should have a negative impact on a firm's financial leverage. Consequently, unemployment risk and the compensation that employees demand may be reduced if firms maintain conservative financial policies that reduce leverage and financial distress (Sharpe, 1994; Hanka, 1998; Falato and Liang, 2015). Nevertheless, if unemployment insurance laws are strong, firms react to this lower unemployment risk with more levered capital structures (Agrawal and Matsa, 2013; Brown and Matsa, 2016). Indeed, Ben-Nasr (2019) recently found evidence that unemployment insurance benefits in the USA have reduced unemployment risk and have led to an increase in bank debt.

However, the relationship between direct labour rights and leverage might also be negative. Some research shows that better legal protection could increase operational fixed costs, hinder workforce adjustments, and increase the likelihood of financial distress (MacKay, 2003; Serfling, 2013; Simintzi et al., 2015; Serfling, 2016; Suzuki and Zushi, 2020). Hiring and firing costs as well as unions are good examples of these direct labour rights that have an effect on workforce adjustment and on operating leverage (Kuzmina, 2013; 
Table 1

Distribution of the sample by countries.

\begin{tabular}{llll}
\hline & Firms & $\%$ & Observations \\
\hline Germany & 605 & $20.9 \%$ & 5,837 \\
Spain & 130 & $4.5 \%$ & 1,122 \\
France & 718 & $24.8 \%$ & 6,854 \\
Italy & 242 & $8.4 \%$ & 2,119 \\
U.K. & 1,197 & $41.4 \%$ & 10,363 \\
Total & 2,892 & $100 \%$ & $26.0 \%$ \\
\hline
\end{tabular}

Simintzi et al., 2015; Woods et al., 2019). In order to face up to this risk, firms might decrease their financial leverage (Dugan et al., 1994; Mauer and Triantis, 1994). Gustafson and Kotter (2018) provide evidence that the financial leverage of US labour intensive firms decreases in response to a federal rise in the minimum wage. In the same vein, Bell and Machin (2018) find that after the minimum wage announcement in 2015 in the UK, expected profits fell significantly, causing a rise in the probability of financial distress.

The negative relationship between employees' indirect labour rights and leverage is also possible. Insofar as employees must allocate their time between work and leisure, wages can be seen as the opportunity cost of free time (Becker, 1965). Thus, if unemployment insurance benefits were to increase, the opportunity cost of leisure would be diluted, and employees would have less incentive to work. In these conditions, since the firm's bankruptcy is less harmful to employees, they might be willing to negotiate better conditions, and firms will have to accept higher wages in order to keep employees or attract new ones. Jayadev (2007); Onaran (2009) and Stockhammer (2017) find a positive relationship between the size of the welfare state -measured through government social spending- and wages, which proves that a greater welfare state implies greater employee bargaining power. In such conditions, firms could try to alleviate labour pressure by reducing the debt burden.

Accordingly, we propose a non-linear relationship between (direct or indirect) labour rights and financial leverage. In the initial stage, when these rights grow but are still low, employees' bargaining power remains weak, and firms are able to increase their leverage. In contrast, when labour rights are high, employees' bargaining power will be strong, and firms will alleviate this pressure by decreasing leverage. The above reasons lead to the following hypothesis:

H3. The relationship between leverage and employees' labour rights is an inverted U-shape: positive for low levels of rights and negative for high levels of rights.

\subsection{Labour market imperfections: downward wage rigidity}

Broadly speaking, sticky wages prevent firms from adapting to changes in the economic environment and can impact firms' financial solvency as well as their flexibility to deal with new situations. There are three main theories related to the causes of this stickiness. The first argument lies in the so-called menu cost or cost of communicating new prices, which discourages price changes (Mankiw and Reis, 2006). In addition, employers can pay efficiency wages that exceed the average market wage in an attempt to encourage employees to make an optimal effort and to generate an opportunity cost, should they fail to make such an effort and be fired (Shapiro and Stiglitz, 1984). According to the insider-outsider theory (Lindbeck and Snower, 1988), current workers —insiders- can push their wages up because employers prefer not to hire new workers - outsiders - at a lower wage because of the recruitment and training costs and the possible lack of incumbent cooperation with the new workers.

The literature has repeatedly found that firms are reluctant to cut wages even during downturns (Dickens et al., 2007; Bertola et al., 2012). Park and Shin (2019) have even found the degree of downward nominal wage rigidity to be countercyclical in the Korean labour market, and that this relationship becomes stronger during a deflationary recession. Schoefer (2015) and Matsa (2018) report that the burden associated with rigid wages increases firms' operating leverage, causes bankruptcies and leads to a reduction in firms' optimal financial leverage. As a consequence, we can expect a negative relationship between downward wage rigidity and leverage.

Nevertheless, the competition level of the goods and services market in which firms operate could moderate this negative relationship. If markets are imperfect, firms can set a price equal to the marginal cost plus a price-cost margin that depends on firms' market power (Blanchard, 2017). Thus, in a non-competitive industry, when firms have a certain degree of monopoly power, they can set price-cost mark-ups and alleviate their downward labour cost rigidity. Based on these arguments, the hypothesis for the relationship between downward wage rigidity and leverage is twofold:

H4a. The relationship between leverage and downward wage rigidity is negative.

H4b. The firm's market power attenuates the negative relationship between leverage and downward wage rigidity.

\section{Research method}

\subsection{Sample}

The sample includes all the non-financial listed firms from five European Union countries (Germany, Spain, France, Italy, and the United Kingdom) and is made up of 26,295 firm-year observations from 2,892 firms from different sectors for 2003-2015. Firms' financial information was collected from the Osiris and Orbis databases (Bureau van Dijk). Each country's macroeconomic data are 
taken from Eurostat, the Organization for Economic Co-operation and Development (OECD), and the International Labor Organization (ILO) databases. Given the heterogeneity in labour laws and reforms across countries we rely on these objective and quantifiable datasets. The distribution of the sample (countries, firms, and observations) can be seen in Table 1 .

\subsection{Variables}

The dependent variable is the leverage ratio (LEV1) of firm $\mathrm{i}$ at the end of period $\mathrm{t}$

$$
L E V 1_{i, t}=\frac{L T D_{i, t}+S T D_{i, t}}{T A_{i, t}}
$$

where $L T D_{i, t}$ is long-term debt excluding provision, pension fund provisions, deferred taxes and deferred income of the firm, $S T D_{i, t}$ is short term debt, and $T A_{i, t}$ is total assets.

Among the independent variables, there is a group of six variables which aim to capture the firm-level characteristics traditionally seen as determinants of leverage (Titman and Wessels, 1988; Rajan and Zingales, 1995; Flannery and Rangan, 2006; Daskalakis et al., 2017; Morandi and Paulet, 2019): 1) Leverage of the previous period ( $\left.L E V 1_{\mathrm{t}-1}\right)$, so as to take into account the partial adjustment to the target leverage as described in more detail in the empirical model section; 2) Growth opportunities (MTB), measured as the sum of the equity market value plus total debt scaled by total assets. Myers (1977) predicts an inverse relationship between growth opportunities and leverage as a result of the transfer of wealth to shareholders from creditors; 3) Profitability (ROA), measured as the ratio of earnings before interest and taxes $(E B I T)$ to total assets. The pecking order theory predicts a negative relationship because of the preference for retained earnings rather than external funds; 4) Non-debt tax shields (NDTS), measured as the ratio of depreciation expenses to total assets. Tax deductions might act as a substitute of interest tax shields and decrease leverage; 5) Tangibility (TANG), measured as tangible assets to total assets. The more tangible the assets, the more collateral and the greater the ability to alleviate the agency cost of debt; and 6) the size of the firm (SIZE), measured as a natural logarithm of total assets. Large firms are usually more diversified and have less cash flow volatility and default probability.

Second, we also include a group of six independent variables that are designed to measure the macroeconomic and institutional environment: 1) the unemployment rate (UNE), measured as the number of unemployed people as a percentage of the labour force; 2) the inflation rate (INF) is defined as the annual rate of change in the consumer price index; 3) Employees' direct rights are measured through three metrics: collective bargaining coverage $(C B C)$, defined as the proportion of employees influenced by collective negotiation (Woods et al. 2019); trade union density (TUD), defined as the proportion of employees that are trade union members (Matsa, 2010), and the ratio of minimum wages to median wages (Gustafson and Kotter, 2018), (MWM); 4) Employees' indirect rights are measured with the unemployment protection ratio (UNP), defined as the ratio of public spending on unemployment, i.e., expenditure on cash benefits to GDP for people in order to compensate for unemployment. It includes expenditure on different public programmes such as out-of-work income maintenance and support, training, and employment or start-up incentives; 5) Downward wage rigidity $(D W R)$ is measured as the wage share, i.e. the proportion of wages to GDP, and is based on the bargaining power theory (Blanchard and Giavazzi, 2003; Stockhammer, 2017); 6) Market power is the ability to alter prices relative to levels of competition, for their own benefit (Stoft, 2002). The risk of exercising market power is associated with market concentration (Besanko et al., 2012). ${ }^{1}$ We use two measures to quantify market power: the Herfindahl Hirschman index (2-digit SIC level) (MPH), which is the sum of the squared percentages of participation of each firm in the market; and market share (2-digit SIC level) (MPS), which is the percentage or market share corresponding to each firm.

\subsection{Empirical model}

Our method is based on the theory of dynamic adjustment of capital structure, according to which firms pursue a target level of financial leverage $\left(L E V_{i, t}^{*}\right)$. We use a dynamic model of partial adjustment in two stages that allows target debt ratios to vary for each firm and over time (Hovakimian et al., 2001).

In the first stage, the target leverage $L E V^{*}{ }_{i, t}$ is regressed against the set of microeconomic (MIC) and macroeconomic (MAC) variables described in paragraph 3.2. (Fama and French, 2002; Kayhan and Titman, 2007).

$$
\mathrm{LEV}_{\mathrm{i}, \mathrm{t}}^{*}=\beta^{0}+\sum_{\mathrm{j}=1}^{5} \beta^{\mathrm{j}} \mathrm{MIC}_{\mathrm{i}, \mathrm{t}}^{\mathrm{j}}+\sum_{\mathrm{k}=1}^{6} \gamma^{\mathrm{k}} \mathrm{MAC}_{\mathrm{i}, \mathrm{t}}^{\mathrm{k}}+\eta_{\mathrm{i}}+\varepsilon_{\mathrm{i}, \mathrm{t}}
$$

where sub-index i identifies each firm and sub-index $t$ indicates the observation year. The second stage includes the transaction costs that prevent firms from immediately adjusting their current leverage $L E V_{i, t}$ to the target $L E V_{\mathrm{i}, \mathrm{t}}^{*}$. Consequently, these costs lead to a process of partial adjustment (De Miguel and Pindado, 2001) described through the following equation:

$$
\mathrm{LEV}_{\mathrm{i}, \mathrm{t}}-\mathrm{LEV}_{\mathrm{i}, \mathrm{t}-1}=\alpha\left(\mathrm{LEV}_{\mathrm{i}, \mathrm{t}}^{*}-\mathrm{LEV}_{\mathrm{i}, \mathrm{t}-1}\right), 0<\alpha<1
$$

\footnotetext{
${ }^{1}$ However, incentives are needed to exert market power since there may be concentrated markets where companies set competitive prices, as the theory of contestable markets points out, given the threat of new competitors (Baumol et al., 1982)
} 
Table 2

Correlations matrix of the variables.

\begin{tabular}{|c|c|c|c|c|c|c|c|c|c|c|c|c|c|c|}
\hline & LEV1 & MTB & TANG & SIZE & ROA & NDTS & UNE & INF & $\mathrm{CBC}$ & TUD & UNP & MWC & DWR & MPH \\
\hline MTB & 0.9930 & 1 & & & & & & & & & & & & \\
\hline TANG & -0.0017 & -0.0150 & 1 & & & & & & & & & & & \\
\hline SIZE & -0.0449 & -0.0627 & 0.3598 & 1 & & & & & & & & & & \\
\hline ROA & -0.4637 & -0.4652 & 0.0150 & 0.0588 & 1 & & & & & & & & & \\
\hline NDTS & 0.0045 & 0.0057 & 0.0084 & -0.0993 & -0.0767 & 1 & & & & & & & & \\
\hline UNE & 0.0043 & -0.0028 & -0.0248 & 0.1135 & 0.0013 & -0.0387 & 1 & & & & & & & \\
\hline INF & -0.0013 & -0.0021 & 0.0604 & -0.0042 & 0.0021 & -0.0012 & -0.1618 & 1 & & & & & & \\
\hline $\mathrm{CBC}$ & 0.0132 & 0.0037 & -0.2352 & 0.0270 & -0.0042 & -0.0579 & 0.4444 & -0.2784 & 1 & & & & & \\
\hline TUD & -0.0126 & -0.0044 & 0.2172 & -0.0159 & 0.0042 & 0.0514 & -0.3342 & 0.3389 & -0.9181 & 1 & & & & \\
\hline UNP & 0.0128 & 0.035 & -0.1806 & 0.0699 & -0.0040 & -0.0550 & 0.6895 & -0.3230 & 0.8929 & -0.7958 & 1 & & & \\
\hline MWC & 0.0116 & 0.0086 & -0.1528 & -0.0833 & -0.0077 & -0.0235 & -0.2278 & -0.2519 & 0.5414 & -0.6069 & 0.2783 & 1 & & \\
\hline DWR & 0.0007 & 0.0052 & 0.1294 & -0.0549 & -0.0069 & 0.0299 & -0.1957 & 0.1628 & -0.4713 & 0.4471 & -0.3953 & -0.0198 & 1 & \\
\hline MPH & 0.0120 & 0.0049 & 0.0962 & 0.0913 & -0.0077 & 0.0103 & 0.1310 & -0.0561 & 0.2363 & -0.2355 & 0.2282 & 0.1010 & -0.1204 & 1 \\
\hline MPS & -0.0028 & -0.0058 & 0.0723 & 0.2980 & 0.0091 & -0.0113 & -0.0046 & -0.0210 & -0.0073 & -0.0040 & -0.0109 & 0.0154 & 0.0094 & 0.2062 \\
\hline
\end{tabular}


Table 3

Descriptive statistics of the variables for the whole sample.

\begin{tabular}{|c|c|c|c|c|c|c|c|}
\hline & Variables & Obs. & Mean & Std. Dev. & Min. & Max. & Median \\
\hline \multirow{5}{*}{ Firm level } & LEV1 & 26,033 & 0.50 & 0.20 & 0.15 & 0.89 & 0.50 \\
\hline & MTB & 26,295 & 1.58 & 0.95 & 0.68 & 4.37 & 1.23 \\
\hline & TANG & 32,639 & 0.50 & 0.26 & 0.06 & 0.93 & 0.50 \\
\hline & SIZE & 32,639 & 11.95 & 2.37 & 7.93 & 16.47 & 11.82 \\
\hline & ROA & 32,392 & 0.002 & 0.162 & -0.48 & 0.21 & 0.04 \\
\hline \multirow{10}{*}{ Labour market } & NDTS & 31,793 & 0.041 & 0.040 & 0 & 0.140 & 0.032 \\
\hline & UNE & 46,890 & 0.079 & 0.032 & 0.04 & 0.26 & 0.08 \\
\hline & INF & 46,890 & 0.018 & 0.010 & -0.01 & 0.04 & 0.03 \\
\hline & $\mathrm{CBC}$ & 46,890 & 0.60 & 0.27 & 0.26 & 0.99 & 0.30 \\
\hline & TUD & 46,890 & 0.196 & 0.097 & 0 & 0.30 & 0.20 \\
\hline & MWM & 46,890 & 0.375 & 0.237 & 0 & 0.67 & 0.46 \\
\hline & UNP & 46,890 & 0.008 & 0.009 & 0 & 0.03 & 0.01 \\
\hline & DWR & 46,890 & 0.571 & 0.018 & 0.52 & 0.60 & 0.57 \\
\hline & MPH & 46,890 & 0.499 & 0.5 & 0 & 1 & 0 \\
\hline & MPS & 31,831 & 0.0024 & 0.0109 & 0 & 0.5263 & 0 \\
\hline
\end{tabular}

Mean, standard deviation, minimum, maximum and median of the dependent and independent variables.

Table 4

Descriptive statistics of the mean of the variables by country.

\begin{tabular}{|c|c|c|c|c|c|c|c|}
\hline & & Germany & Spain & France & Italy & U.K. & Total \\
\hline \multirow{6}{*}{ Firm level } & LEV1 & 0.4631 & 0.5566 & 0.5390 & 0.5543 & 0.4750 & 0.5015 \\
\hline & МТВ & 1.5428 & 1.3948 & 1.4523 & 1.3163 & 1.7643 & 1.5820 \\
\hline & TANG & 0.4843 & 0.5663 & 0.4385 & 0.5139 & 0.5383 & 0.5017 \\
\hline & SIZE & 11.89 & 13.35 & 11.95 & 13.03 & 11.63 & 11.95 \\
\hline & $\mathrm{ROA}$ & 0.0178 & 0.0336 & 0.0167 & 0.0340 & -0.0229 & 0.0022 \\
\hline & NDTS & 0.0448 & 0.0356 & 0.0380 & 0.0425 & 0.0405 & 0.0407 \\
\hline \multirow{9}{*}{ Labour market } & UNE & 0.074 & 0.1633 & 0.0913 & 0.0906 & 0.0613 & 0.0792 \\
\hline & INF & 0.0153 & 0.02 & 0.0153 & 0.018 & 0.0213 & 0.0183 \\
\hline & $\mathrm{CBC}$ & 0.614 & 0.775 & 0.976 & 0.800 & 0.3193 & 0.5995 \\
\hline & TUD & 0.19 & 0.1486 & 0.0746 & 0.3233 & 0.2493 & 0.1955 \\
\hline & MWM & 0.063 & 0.374 & 0.633 & 0 & 0.460 & 0.375 \\
\hline & UNP & 0.013 & 0.023 & 0.017 & 0.005 & 0 & 0.0082 \\
\hline & DWR & 0.563 & 0.564 & 0.572 & 0.529 & 0.582 & 0.571 \\
\hline & MPH & 0.583 & 0.567 & 0.567 & 0.602 & 0.389 & 0.499 \\
\hline & MPS & 0.0026 & 0.0020 & 0.0028 & 0.0027 & 0.0021 & 0.0024 \\
\hline
\end{tabular}

where $L E V_{i, t}$ and $L E V_{i, t-1}$ are current and previous leverage, respectively, and $L E V_{i, t}^{*}$ is the objective or target leverage.

Transaction costs are introduced through the coefficient $\alpha$. If these costs are zero, i.e., $\alpha=1$, then $L E V_{i, t}=L E V_{i, t}^{*}$ and the firm automatically adjusts its leverage to the target. Conversely, if $\alpha=0$, then $L E V_{i, t}=L E V_{i, t-1}$, which implies that transaction costs are so high that the firm does not adjust its level of leverage at all, and that financial leverage remains at the same level as in the previous period. In intermediate situations, when the value of $\alpha$ is between 0 and 1 , firms adjust their leverage inversely proportionally to transaction costs. Clearing the current leverage $L E V_{i, t}$ of the Eq. (2), we obtain:

$$
\mathrm{LEV}_{\mathrm{i}, \mathrm{t}}=\alpha \mathrm{LEV}_{\mathrm{i}, \mathrm{t}}^{*}+(1-\alpha) \mathrm{LEV}_{\mathrm{i}, \mathrm{t}-1}
$$

Finally, incorporating Eq. (1) into Eq. (3) and taking into account that the estimates are run with a data panel, we obtain the equation of the econometric model that is used to test the hypotheses:

$$
\mathrm{LEV}_{\mathrm{i}, \mathrm{t}}=\alpha \beta^{0}+(1-\alpha) \mathrm{LEV}_{\mathrm{i}, \mathrm{t}-1}+\sum_{\mathrm{j}=1}^{5} \alpha \beta^{\mathrm{j}} \mathrm{MIC}_{\mathrm{i}, \mathrm{t}}^{\mathrm{j}}+\sum_{\mathrm{k}=1}^{6} \alpha \gamma^{\mathrm{k}} \mathrm{MAC}_{\mathrm{i}, \mathrm{t}}^{\mathrm{k}}+\alpha \eta_{\mathrm{i}}+\alpha \varepsilon_{\mathrm{i}, \mathrm{t}}
$$

where $\alpha \eta_{\mathrm{i}}$ is the fixed effect of firm $\mathrm{i}$, and $\alpha \varepsilon_{\mathrm{i}, \mathrm{t}}$ is the random disturbance.

The so-called fixed effects, that is, specific effects or influences associated to each firm $\left(\eta_{\mathrm{i}}\right)$, require the panel data methodology. In auto-regressive models such as ours, when the lagged dependent variable (leverage) acts as an explanatory variable, a problem of endogeneity could arise. In order to avoid inconsistent estimates, one suitable technique is the generalized method of moments (GMM) (Arellano and Bond, 1991). Specifically, the system estimator version of GMM (Blundell and Bond, 1998) is applied. This version not only corrects problems of simultaneity and observational errors, but also allows a robust residual structure to be managed so as to prevent heteroscedasticity and autocorrelation problems. The system estimator GMM is applied through the Stata 14.2 econometric package. 
Table 5

Relevant macroeconomic variables in the labour market: unemployment and inflation.

\begin{tabular}{lll}
\hline & $(1)$ & $(2)$ \\
\hline LEV1 $1_{\mathrm{t}-1}$ & $0.4494^{* * *}$ & $0.5456^{* * *}$ \\
MTB & $(0.0000)$ & $(0.0000)$ \\
& -0.0025 & 0.0134 \\
TANG & $(0.7780)$ & $(0.4391)$ \\
& -0.0905 & -0.0223 \\
SIZE & $(0.5965)$ & $(0.8805)$ \\
& $0.0571^{* * *}$ & -0.0079 \\
ROA & $(0.0003)$ & $(0.6401)$ \\
& $-0.4148^{* * *}$ & 0.2993 \\
NDTS & $(0.0000)$ & $(0.1692)$ \\
& 0.0876 & $2.5057^{* * *}$ \\
UNE & $(0.8798)$ & $(0.0004)$ \\
& $-1.4875^{* * *}$ & \\
INF & $(0.0000)$ & $0.6021^{* *}$ \\
Observations & & $(0.0129)$ \\
Wald test & & 18,548 \\
AR1 & 16,746 & $349.9^{* * *}$ \\
AR2 & $217.1^{* * * *}$ & $-5.142^{* * *}$ \\
Hansen test & $-7.145^{* * *}$ & -1.405 \\
\hline
\end{tabular}

The dependent variable $\mathrm{LEV} 1_{\mathrm{t}}$ is defined as the ratio of long-term debt excluding provision, pension fund provisions, deferred taxes and deferred income and short term debt to total assets at the end of period $t$; $L E V 1_{t-1}$ : debt ratio at time $t-1$; MTB is the equity market-tobook ratio opportunities; TANG: tangible assets to total assets; SIZE: natural logarithm of total assets; ROA: return on assets; NDTS: amortization to total assets; UNE: unemployment rate; INF: inflation rate. Estimated coefficients and $\mathrm{p}$-values $(\mathrm{P}>|\mathrm{z}|)$ in parentheses. The Wald test contrasts the joint significance of the explanatory variables. AR1 and AR2 are first and second order serial correlation statistics. The Hansen test is distributed as a $\chi^{2}$ with degrees of freedom equal to the number of estimated coefficients and tests the validity of the instruments. ${ }^{* * *},{ }^{* *}, *$ : statistical significance at the $1 \%, 5 \%$ and $10 \%$ level.

\section{Empirical results}

\subsection{Descriptive analysis}

The empirical analysis consists of two stages. Firstly, the sample under study is described through some descriptive statistics. Table 2 shows the correlation matrix among the independent variables. The correlations are low enough to rule out the possibility of multicollinearity. The exceptions are some labour market variables which enter the model estimation separately.

Table 3 shows the mean, standard deviation, minimum, maximum, and median value of the dependent variable as well as the explanatory variables at both firm and labour market level. In addition, Table 4 reports the mean value of the variables across countries.

The mean value of the dependent variable $L E V 1$ is around 0.5 , with some minor differences across countries: German firms have the lowest debt ratio, whereas Spanish ones are the most leveraged. There are also some differences in terms of growth opportunities $(M T B)$ and performance $(R O A)$, with British firms having the most growth opportunities but the lowest (negative) ROA. In contrast, Italian firms exhibit the lowest MTB value and the highest $R O A$ value.

As regards the macroeconomic variables, the unemployment rate (UNE) is especially high in Spain. There are also substantial differences in collective bargaining coverage $(C B C)$ and trade union power (TUD), with France and Italy standing out, respectively. Other important international imbalances concern minimum wages (MWM), and the level of market power $(M P H)$.

\subsection{Explanatory analysis}

The results of the explanatory analysis are shown in Tables 5-7. In Table 5, we report the estimates of the relationship with unemployment and inflation, in Table 6 those reflecting employees' rights, and in Table 7 those dealing with downward wage rigidity. In each table there are different columns which are conditional on the characteristics of the labour market under study.

In Table 5, current financial leverage is a function of previous leverage, firm-level variables, the unemployment rate, and the inflation rate. It can be seen that the lagged leverage $\left(L E V 1_{t-1}\right)$ is positively related to the current one. This result confirms the existence of a target capital structure, with a speed of adjustment between 0.45 and 0.55 . Similar results have been found by Gonzalez and González (2008) and Cook and Tang (2010). In the first column, the coefficient of the SIZE variable is positive, consistent with the trade-off theory of capital structure, and the negative estimate of profitability $(R O A)$ can be explained by the pecking order theory. These results are in line with those of Drobetz et al. (2015); Flannery and Rangan (2006); Frank and Goyal (2009); Halling et al. (2016). 
Table 6

Labour market imperfections: employees' rights.

\begin{tabular}{|c|c|c|c|c|}
\hline & (1) & (2) & (3) & (4) \\
\hline $\mathrm{LEV} 1_{\mathrm{t}-1}$ & $\begin{array}{l}0.2659^{*} \\
(0.0841)\end{array}$ & $\begin{array}{l}0.5699 * * * \\
(0.0000)\end{array}$ & $\begin{array}{l}0.7756 * * * \\
(0.0000)\end{array}$ & $\begin{array}{l}0.7104^{* * * *} \\
(0.0000)\end{array}$ \\
\hline MTB & $\begin{array}{l}-0.0593^{* * *} \\
(0.0000)\end{array}$ & $\begin{array}{l}-0.0335^{* * *} \\
(0.0013)\end{array}$ & $\begin{array}{l}-0.0185 \\
(0.3698)\end{array}$ & $\begin{array}{l}-0.0407 * * * \\
(0.0005)\end{array}$ \\
\hline TANG & $\begin{array}{l}-0.8524^{* * * *} \\
(0.0004)\end{array}$ & $\begin{array}{l}-0.2914 \\
(0.1314)\end{array}$ & $\begin{array}{l}-0.6448^{* * *} \\
(0.0039)\end{array}$ & $\begin{array}{l}-1.1763^{* * * *} \\
(0.0000)\end{array}$ \\
\hline SIZE & $\begin{array}{l}0.0070 \\
(0.8327)\end{array}$ & $\begin{array}{l}0.0265 \\
(0.1796)\end{array}$ & $\begin{array}{l}0.0306 \\
(0.1289)\end{array}$ & $\begin{array}{l}0.0460^{* * *} \\
(0.0117)\end{array}$ \\
\hline ROA & $\begin{array}{l}0.0181 \\
(0.1260)\end{array}$ & $\begin{array}{l}0.0042 \\
(0.6507)\end{array}$ & $\begin{array}{l}-0.1050^{* *} \\
(0.0110)\end{array}$ & $\begin{array}{l}0.1462^{* * *} \\
(0.0020)\end{array}$ \\
\hline NDTS & $\begin{array}{l}0.5775^{* *} \\
(0.0342)\end{array}$ & $\begin{array}{l}0.4837 * * \\
(0.031)\end{array}$ & $\begin{array}{l}0.3232^{* * *} \\
(0.0057)\end{array}$ & $\begin{array}{l}0.6764 * * \\
(0.0385)\end{array}$ \\
\hline $\mathrm{CBC}$ & $\begin{array}{l}2.2259^{* *} \\
(0.0137)\end{array}$ & & & \\
\hline $\mathrm{CBC}^{2}$ & $\begin{array}{l}-1.9901 * * * \\
(0.0091)\end{array}$ & & & \\
\hline UNP & & $\begin{array}{l}9.4855^{* *} \\
(0.0189)\end{array}$ & & \\
\hline $\mathrm{UNP}^{2}$ & & $\begin{array}{l}-410.8269^{* * *} \\
(0.0022)\end{array}$ & & \\
\hline TUD & & & $\begin{array}{l}1.6383^{* *} \\
(0.0233)\end{array}$ & \\
\hline TUD $^{2}$ & & & $\begin{array}{l}-6.9644 * * \\
(0.0244)\end{array}$ & \\
\hline MWM & & & & $\begin{array}{l}0.8280^{* *} \\
(0.0115)\end{array}$ \\
\hline $\mathrm{MWM}^{2}$ & & & & $\begin{array}{l}-1.5215^{* *} \\
(0.0200)\end{array}$ \\
\hline Observations & 19,370 & 19,370 & 18,933 & 19,370 \\
\hline Wald test & $129.9 * * *$ & $219.9 * * *$ & $158.1^{* * *}$ & $61.01 * * *$ \\
\hline AR1 & $-1.894 * *$ & $-3.999 * * *$ & $-5.149 * * *$ & $-1.342 * * *$ \\
\hline AR2 & 1.638 & 0.802 & -0.748 & -1.156 \\
\hline Hansen test & 11.99 & 12.02 & 10.06 & 18.68 \\
\hline
\end{tabular}

The dependent variable $\mathrm{LEV} 1_{\mathrm{t}}$ is defined as the ratio of long-term debt excluding provision, pension fund provisions, deferred taxes and deferred income and short term debt to total assets at the end of period $t$; $\mathrm{LEV}_{\mathrm{t}-1}$ : debt ratio at time $\mathrm{t}-1$; MTB: growth opportunities; TANG: tangibility of assets; SIZE: natural logarithm of the total volume of assets; ROA: EBIT/total assets; NDTS: amortization between total assets; CBC: proportion of employees influenced by collective negotiation; UNP: public spending on unemployment or expenditure on cash benefits for people to compensate for unemployment by GDP; TUD: proportion of employees that are trade union members; MWM: ratio of minimum wages to median wages. Estimated coefficients and p-values $(P>|z|)$ in parentheses. The Wald test contrasts the joint significance of the explanatory variables. AR1 and AR2 are first and second order serial correlation statistics. The Hansen test is distributed as a $\chi^{2}$ with degrees of freedom equal to the number of estimated coefficients. $* * *, * *, *$ : statistical significance at the $1 \%, 5 \%$ and $10 \%$ level.

In contrast, the tax shield alternative to debt (NDTS) in the second column is positive. Although this result contradicts the trade-off theory, a number of studies have found the same result (Antoniou et al., 2008; Frank and Goyal, 2009; Mao, 2003; Titman and Wessels, 1988), which could be possible when the depreciation of tangible assets is the major component of non-debt tax shields. In addition, depreciation is likely to be correlated with fixed assets, which act as collateral and enhance financial leverage (DeAngelo and Masulis, 1980).

More importantly, the unemployment rate (UNE) is negatively and significantly related to leverage (Column 1 in Table 5), and the coefficient of the inflation rate (INF) is positive and significant (Column 2). Both results confirm our first two hypotheses concerning the relationship between unemployment (H1), inflation (H2), and capital structure. The AR2 and the Hansen tests show that there are no concerns vis-à-vis second-order serial correlation and the validity of the instrumental variables.

Table 6 reports the relationship between capital structure and employees' rights. Since there are both direct and indirect rights, we run separate regressions for each. In columns 1 and 2, we check for a possible non-linear relationship with collective bargaining coverage $(C B C)$ and unemployment protection (UNP). In both cases, our results support hypothesis $\mathrm{H} 3$, according to which the initial positive relationship for low levels of employees' rights turns negative after a given threshold. According to our calculations, the inflection point would be around $56 \%$ of collective bargaining coverage and $1.1 \%$ of unemployment protection. Both figures are consistent with the descriptive statistics reported in Table 3. Furthermore, as can be seen in Table 4, the average value of $C B C$ for the UK is under the $56 \%$ threshold, whereas the average value in the other four continental countries is above this threshold. To some extent, it seems that collective bargaining coverage displays an asymmetric relationship with financial leverage in "Anglo-Saxon" vs. continental European countries.

In columns 3 and 4, we check for the relationship between capital structure and two other measures of direct employees' rights: trade union density (TUD) and the ratio of minimum wages to median wages (MWM). Once again, we find a non-linear relationship, and the inflection points $(11.8 \%$ and $27.2 \%)$ are consistent with our descriptive statistics. 
Table 7

Labour market imperfections: downward wage rigidity.

\begin{tabular}{|c|c|c|c|}
\hline & (1) & (2) & (3) \\
\hline $\mathrm{LEV} 1_{\mathrm{t}-1}$ & $\begin{array}{l}0.5674 * * * \\
(0.0013)\end{array}$ & $\begin{array}{l}0.3937^{* * *} \\
(0.0000)\end{array}$ & $\begin{array}{l}0.5951^{* * *} \\
(0.0000)\end{array}$ \\
\hline МТВ & $\begin{array}{l}-0.0296^{* * * *} \\
(0.0073)\end{array}$ & $\begin{array}{l}-0.0123 \\
(0.1117)\end{array}$ & $\begin{array}{l}-0.0580^{* * *} \\
(0.0021)\end{array}$ \\
\hline TANG & $\begin{array}{l}-0.0842 \\
(0.6591)\end{array}$ & $\begin{array}{l}0.1609 \\
(0.3638)\end{array}$ & $\begin{array}{l}0.2399^{* * *} \\
(0.0500)\end{array}$ \\
\hline SIZE & $\begin{array}{l}0.0144 \\
(0.4561)\end{array}$ & $\begin{array}{l}0.0520^{* * *} \\
(0.0000)\end{array}$ & $\begin{array}{l}-0.1514^{* *} \\
(0.0343)\end{array}$ \\
\hline ROA & $\begin{array}{l}0.0042 \\
(0.9866)\end{array}$ & $\begin{array}{l}-0.2206^{* * *} \\
(0.0000)\end{array}$ & $\begin{array}{l}-0.6694 * * * \\
(0.0017)\end{array}$ \\
\hline NDTS & $\begin{array}{l}1.2478^{*} \\
(0.0917)\end{array}$ & $\begin{array}{l}0.0863 \\
(0.3512)\end{array}$ & $\begin{array}{l}-1.8969^{* *} \\
(0.0423)\end{array}$ \\
\hline DWR & $\begin{array}{l}-0.8155^{* *} \\
(0.0138)\end{array}$ & $\begin{array}{l}-4.7215^{* * * *} \\
(0.0029)\end{array}$ & $\begin{array}{l}-2.6401 * * * \\
(0.0011)\end{array}$ \\
\hline MPH & & $\begin{array}{l}-4.3186^{* *} \\
(0.0103)\end{array}$ & \\
\hline DWR x MPH & & $\begin{array}{l}7.5384^{* *} \\
(0.0106)\end{array}$ & \\
\hline MPS & & & $\begin{array}{l}-15.206 \\
(0.2210)\end{array}$ \\
\hline DWR x MPS & & & $\begin{array}{l}2.0908^{* *} \\
(0.0273)\end{array}$ \\
\hline Observations & 18,548 & 18,619 & 18,870 \\
\hline Wald test & $142.1^{* * *}$ & $225.2^{* * *}$ & $62.03^{* * *}$ \\
\hline AR1 & $-2.962^{* * *}$ & $-6.196^{* * *}$ & $-2.919^{* * *}$ \\
\hline AR2 & -0.737 & -0.706 & -0.232 \\
\hline Hansen test & 9.230 & 24.95 & 10.09 \\
\hline
\end{tabular}

The dependent variable $\mathrm{LEV} 1_{\mathrm{t}}$ is defined as the ratio of long-term debt excluding provision, pension fund provisions, deferred taxes and deferred income and short term debt to total assets at the end of period $t$; $L E V 1_{t-1}$ : debt ratio at time t-1; MTB: growth opportunities; TANG: tangibility of assets; SIZE: natural logarithm of the total volume of assets; ROA: EBIT/total assets; NDTS: amortization between total assets; DWR: wage share; MPH: Herfindahl Hirschman index; MPS: market share. Estimated coefficients and $p$-values $(P>|z|)$ in parentheses. The Wald test contrasts the joint significance of the explanatory variables. AR1 and AR2 are first and second order serial correlation statistics. The Hansen test is distributed as a $\chi 2$ with degrees of freedom equal to the number of estimated coefficients. $* * * * *, *$ : statistical significance at the $1 \%, 5 \%$ and $10 \%$ level.

As regards the control variables, in addition to the lagged financial leverage, growth opportunities (MTB) have a negative coefficient (as expected, according to the pecking order theory), whereas non-debt tax shields (NDTS) have a positive coefficient, as explained previously.

In Table 7, we report the effect of downward wage rigidity and market power (H4a and H4b). First, the downward wage rigidity $(D W R)$ variable has a negative and significant coefficient (Column 1), thus confirming H4a. In addition, the positive estimate of the interaction with market concentration index $(M P H)$ suggests that the negative relationship is attenuated by market power (Hypothesis 4b) to the extent that the coefficient of the interacted variable is positive. The signs and significance of the control variables (MTB, SIZE, NDTS) are in line with previous estimates. The results remain the same when we measure market power with the firm's market share (MPS), as shown in Column 3.

These empirical findings lend support to the theoretical framework, and indicate that lower unemployment (UNP) improves firms' cash flows and reduces employees' claims for additional compensation for unemployment risk, which increases earnings and reduces bankruptcy costs. Inflation (INF) alleviates the pressure on real wages and reduces the real value of debt, which reduces operational leverage and bankruptcy costs. A low level of employees' rights (CBC and UNP) implies weak bargaining power and less operational leverage, such that firms have a margin to increase their indebtedness. Conversely, when labour rights levels are high, employees' bargaining power will be strong, and firms will alleviate this pressure by decreasing leverage. Downward wage rigidity ( $D W R$ ) prevents the firm from adapting to changes, and has detrimental effects on financial solvency. However, when firms have a certain degree of monopoly power $(M P H)$, they can set price-cost mark-ups in order to alleviate their downward wage rigidity.

As far as the control variables are concerned, firms use less debt when they have more growth opportunities (MTB) or when they generate internal resources, which is consistent with the postulates of the pecking order theory. According to the pecking order theory, the negative sign of ROA indicates that firms prefer to retain earnings. The positive sign of SIZE suggests that larger firms are less subject to asymmetric information problems and can afford a higher level of leverage. Finally, the positive sign of NDTS does not support the prediction of the trade-off theory.

\section{Robustness analysis}

In order to test the consistency of our results, we now perform some robustness analyses using a different measure of the dependent variable (LEV2): 
Table 8

Robustness analysis: unemployment and inflation.

\begin{tabular}{lll}
\hline & $(1)$ & $(2)$ \\
\hline LEV2 & $0.4997^{* * * *}$ & $0.7742^{* * *}$ \\
MTB & $(0.0000)$ & $(0.0000)$ \\
& $-0.0307^{* *}$ & -0.0012 \\
TANG & $(0.0372)$ & $(0.3022)$ \\
& -0.1550 & $-1.1734^{* * *}$ \\
SIZE & $(0.4026)$ & $(0.0000)$ \\
& 0.0092 & $0.0521^{* * *}$ \\
ROA & $(0.5848)$ & $(0.0078)$ \\
& 0.0037 & $-0.5066^{* * *}$ \\
NDTS & $(0.8334)$ & $(0.0034)$ \\
& $0.5906^{* *}$ & $1.9959^{* * *}$ \\
UNE & $(0.0743)$ & $(0.0039)$ \\
& $-0.5450^{* * *}$ & \\
INF & $(0.0147)$ & $0.6567^{* * *}$ \\
& & $(0.0000)$ \\
Observations & & 24,382 \\
Wald test & 24,382 & $749.5^{* * *}$ \\
AR1 & $168.3^{* * *}$ & $-8.945^{* * *}$ \\
AR2 & $-3.299^{* * *}$ & -1.072 \\
Hansen test & -0.478 & 15.16 \\
\hline
\end{tabular}

The dependent variable $\mathrm{LEV} 2_{\mathrm{t}}$ is defined as total liabilities and debt to total assets at the end of period $t$; LEV2 $2_{t-1}$ : debt ratio at time $t-1$; MTB is the equity market-to-book ratio opportunities; TANG: tangible assets to total assets; SIZE: natural logarithm of total assets; ROA: return on assets; NDTS: amortization to total assets; UNE: unemployment rate; INF: inflation rate. Estimated coefficients and p-values $(\mathrm{P}>|\mathrm{z}|)$ in parentheses. The Wald test contrasts the joint significance of the explanatory variables. AR1 and AR2 are first and second order serial correlation statistics. The Hansen test is distributed as a $\chi 2$ with degrees of freedom equal to the number of estimated coefficients and tests the validity of the instruments. $* * * * *$, : statistical significance at the $1 \%, 5 \%$ and $10 \%$ level.

$$
L E V 2_{i, t}=\frac{T L D_{i, t}}{T A_{i, t}}
$$

where $T L D_{i, t}$ is the total liabilities and debt of firm $\mathrm{i}$ at the end of period $\mathrm{t}$, and $T A_{i, t}$ are the total assets of firm $\mathrm{i}$ at the end of period $\mathrm{t}$.

In Table 8, we examine how unemployment and inflation influence capital structure. As can be seen in the first column, the unemployment rate (UNE) has a significant and negative impact. The inflation rate (INF) also has a positive and significant influence (Column 2). These estimates confirm our baseline results reported in Table 5.

In Table 9, we analyse how the new measure of leverage (LEV2) is explained by microeconomic variables and employees' rights. In columns 1 and 2, we test for a possible non-linear relationship with collective bargaining coverage $(C B C)$ and unemployment protection (UNP). In both cases, these variables are initially positively related, and after a given inflection point, the relationship becomes negative, thus confirming hypothesis H3. In columns 3 and 4, we see that union density (TUD) and the ratio of minimum wages to median wages (MWM) display a similar behaviour to the above-mentioned results: an inverted U-shaped quadratic relationship, which is initially positive and then turns negative.

Finally, in Table 10 we explore the effect of downward wage rigidity and market power on capital structure (H4a and H4b). First, the downward wage rigidity (DWR) variable exhibits a negative and significant coefficient (Column 1), thereby confirming H4a. In addition, we find that the effect of downward wage rigidity $(D W R)$ is attenuated by market power (Hypothesis $4 \mathrm{~b}$ ) measured with the market concentration index $(M P H)$ in column 2 and with the firm's market share (MPS) in column 3 . In short, all these results confirm hypotheses 3 and 4 and evidence the robustness of our findings.

The results of the firm-level variables are also similar, once again highlighting the negative relationship of growth opportunities and profitability with the debt rate, in line with the postulates of the pecking order, the negative relationship with the degree of tangibility, and the positive one with non-debt tax shields.

\section{Conclusions}

While capital structure remains one of the core research topics in corporate finance, the latest trends in the field advocate considering the impact of the macroeconomic environment on firms' capital structure. Our study aims to shed some light on how labour market conditions impact this topic. We initially explore the effect on capital structure of two key macroeconomic variables in the labour market: the unemployment and inflation rates. We then examine how labour market imperfections might affect firms' capital structure through employees' rights and downward wage rigidity.

We study a sample of 2,892 non-financial listed firms from five European Union countries (Germany, Spain, France, Italy, and the 
Table 9

Robustness analysis: employees' rights.

\begin{tabular}{|c|c|c|c|c|}
\hline & (1) & (2) & (3) & (4) \\
\hline $\mathrm{LEV}_{\mathrm{t}-1}$ & $\begin{array}{l}0.6556^{* * *} \\
(0.0000)\end{array}$ & $\begin{array}{l}0.8834 * * * \\
(0.0000)\end{array}$ & $\begin{array}{l}0.7938^{* * *} \\
(0.0000)\end{array}$ & $\begin{array}{l}0.6095^{* * *} \\
(0.0000)\end{array}$ \\
\hline MTB & $\begin{array}{l}-0.0652^{* * *} \\
(0.0031)\end{array}$ & $\begin{array}{l}-0.0504^{* * *} \\
(0.0000)\end{array}$ & $\begin{array}{l}0.0006 \\
(0.3496)\end{array}$ & $\begin{array}{l}-0.0905^{* * *} \\
(0.0081)\end{array}$ \\
\hline TANG & $\begin{array}{l}-0.3586^{* * *} \\
(0.0024)\end{array}$ & $\begin{array}{l}-0.0823 \\
(0.4719)\end{array}$ & $\begin{array}{l}-0.4040^{*} \\
(0.0508)\end{array}$ & $\begin{array}{l}0.1022 \\
(0.6235)\end{array}$ \\
\hline SIZE & $\begin{array}{l}0.0021 \\
(0.9165)\end{array}$ & $\begin{array}{l}0.0332^{* * *} \\
(0.0036)\end{array}$ & $\begin{array}{l}0.0071 \\
(0.6164)\end{array}$ & $\begin{array}{l}0.0287 \\
(0.3115)\end{array}$ \\
\hline ROA & $\begin{array}{l}-0.0091 \\
(0.6029)\end{array}$ & $\begin{array}{l}-0.3917^{* k *} \\
(0.0027)\end{array}$ & $\begin{array}{l}-0.0015 \\
(0.7577)\end{array}$ & $\begin{array}{l}-0.7330^{* *} \\
(0.0129)\end{array}$ \\
\hline NDTS & $\begin{array}{l}0.6797^{*} \\
(0.0977)\end{array}$ & $\begin{array}{l}-0.4356 \\
(0.5604)\end{array}$ & $\begin{array}{l}0.1566 \\
(0.2826)\end{array}$ & $\begin{array}{l}-0.3963 \\
(0.7658)\end{array}$ \\
\hline $\mathrm{CBC}$ & $\begin{array}{l}2.3261^{* *} \\
(0.0164)\end{array}$ & & & \\
\hline $\mathrm{CBC}^{2}$ & $\begin{array}{l}-1.6681^{* *} \\
(0.0355)\end{array}$ & & & \\
\hline UNP & & $\begin{array}{l}7.0073^{*} \\
(0.0780)\end{array}$ & & \\
\hline $\mathrm{UNP}^{2}$ & & $\begin{array}{l}-380.3141^{* * * *} \\
(0.0065)\end{array}$ & & \\
\hline TUD & & & $\begin{array}{l}4.9838^{* * *} \\
(0.0293)\end{array}$ & \\
\hline TUD $^{2}$ & & & $\begin{array}{l}-13.3282^{* *} \\
(0.0211)\end{array}$ & \\
\hline MWM & & & & $\begin{array}{l}1.5921^{*} \\
(0.0630)\end{array}$ \\
\hline $\mathrm{MWM}^{2}$ & & & & $\begin{array}{l}-4.8991^{* * *} \\
(0.0092)\end{array}$ \\
\hline Observations & 24,382 & 24,312 & 24,382 & 24,382 \\
\hline Wald test & $2224 * * *$ & $510.7^{* * *}$ & $625.5^{* * *}$ & $286.4^{* * *}$ \\
\hline AR1 & $-1.614^{* * *}$ & $-12.46^{* * *}$ & $-11.04 * * *$ & $-5.250 * * *$ \\
\hline AR2 & 1.296 & 0.994 & 0.440 & -0.518 \\
\hline Hansen test & 18.80 & 32.31 & 14.91 & 34.64 \\
\hline
\end{tabular}

The dependent variable $\mathrm{LEV} 2_{\mathrm{t}}$ is defined as total liabilities and debt to total assets at the end of period t; $\mathrm{LEV} 2_{\mathrm{t}-1}$ : debt ratio at time t-1; MTB: growth opportunities; TANG: tangibility of assets; SIZE: natural logarithm of the total volume of assets; ROA: EBIT/ total assets; NDTS: amortization between total assets; CBC: proportion of employees influenced by collective negotiation; UNP: public spending on unemployment or expenditure on cash benefits for people to compensate for unemployment by GDP; TUD: proportion of employees that are trade union members; MWM: ratio of minimum wages to median wages. Estimated coefficients and p-values $(\mathrm{P}>|\mathrm{z}|)$ in parentheses. The Wald test contrasts the joint significance of the explanatory variables. AR1 and AR2 are first and second order serial correlation statistics. The Hansen test is distributed as a $\chi^{2}$ with degrees of freedom equal to the number of estimated coefficients. $* * *, * *, *$ : statistical significance at the $1 \%, 5 \%$ and $10 \%$ level.

United Kingdom) between 2003 and 2015. Consistent with previous studies, our results confirm that labour market conditions influence firms' capital structure.

First, we find that financial leverage is negatively related to the unemployment rate and positively related to the inflation rate. Second, our results suggest a non-linear relationship with employees' labour rights: positive for low levels of labour rights and negative for high levels. Third, we find a negative relationship with downward wage rigidity, although this effect is moderated by firms' market power.

Our study is not without limitations. Despite being representative of the largest European countries, the sample includes only five nations. Although we control for country-level specific factors, there are some institutional differences across countries, such as tax reforms, that could be introduced in further analyses. Tax reforms modify employees' net income and can lead to a different demand for their labour rights in response to the change of income in order to maintain the same opportunity cost of leisure. Future research also could address the role of labour productivity, which increases employees' bargaining power and could be a substitute for labour rights given that employees can obtain better conditions in their individual employment contracts. In addition, our research raises some labour market issues that call for new analyses, such as employee equity ownership. In the modern knowledge economy, a new avenue of research to be explored might be the link between investments in specific human capital and corporate financing decision. Moreover, it may be useful to study the effect of intellectual property on capital structure as a governance mechanism to protect firms from the loss of talented employees.

The main implication to emerge from our findings is that firms should make decisions taking into account not only their specific financial characteristics (the usual determinants of capital structure such as growth opportunities, assets structure, financial performance, etc.), but also the labour market conditions in which they operate. In turn, if they are to achieve the optimal financial structure, managers should keep in mind unemployment and inflation conditions, employees' bargaining power, the level of downward wage rigidity, and firms' market power. Our study also has useful implications for policymakers since our results show the multifaceted implications of countries' labour markets and that the interests of employees and firms must be balanced in order to avoid a firm's 
Table 10

Robustness analysis: downward wage rigidity.

\begin{tabular}{|c|c|c|c|}
\hline & (1) & (2) & (3) \\
\hline \multirow{2}{*}{$\mathrm{LEV}_{\mathrm{t}-1}$} & $0.9250^{* * *}$ & $0.6355^{* * *}$ & $0.7440^{* * * *}$ \\
\hline & $(0.0000)$ & $(0.0000)$ & $(0.0000)$ \\
\hline \multirow[t]{2}{*}{ MTB } & $-0.0391^{* * *}$ & 0.0003 & -0.0022 \\
\hline & $(0.0000)$ & $(0.6292)$ & $(0.1363)$ \\
\hline \multirow[t]{2}{*}{ TANG } & -0.1338 & 0.1365 & 0.2331 \\
\hline & $(0.4253)$ & $(0.3045)$ & $(0.1368)$ \\
\hline \multirow[t]{2}{*}{ SIZE } & 0.0251 & $0.0185^{* * *}$ & -0.0222 \\
\hline & $(0.1092)$ & $(0.0003)$ & $(0.1846)$ \\
\hline \multirow[t]{2}{*}{ ROA } & 0.2500 & $-0.1969^{* *}$ & $-0.4899^{* * *}$ \\
\hline & $(0.1368)$ & $(0.0225)$ & $(0.0003)$ \\
\hline \multirow[t]{2}{*}{ NDTS } & $1.9551^{* * *}$ & $0.9477^{* * *}$ & $0.7610^{* * * *}$ \\
\hline & $(0.0010)$ & $(0.0000)$ & $(0.0009)$ \\
\hline \multirow[t]{2}{*}{ DWR } & $-0.8162^{* * *}$ & $-3.5011^{* * *}$ & $-1.5841^{* * *}$ \\
\hline & $(0.0003)$ & $(0.0036)$ & $(0.0000)$ \\
\hline \multirow[t]{2}{*}{ MPH } & & $-2.9693^{* *}$ & \\
\hline & & $(0.0229)$ & \\
\hline \multirow[t]{2}{*}{ DWR x MPH } & & $5.1886^{\text {** }}$ & \\
\hline & & $(0.0231)$ & \\
\hline \multirow[t]{2}{*}{ MPS } & & & -12.976 \\
\hline & & & $(0.8261)$ \\
\hline \multirow[t]{2}{*}{ DWR x MPS } & & & $0.4565^{*}$ \\
\hline & & & $(0.0519)$ \\
\hline Observations & 22,774 & 24,382 & 23,916 \\
\hline Wald test & $862.3^{* * *}$ & $1401 * * *$ & $401.4^{* * *}$ \\
\hline AR1 & $-4.348^{* * *}$ & $-4.570^{* * *}$ & $-4.798^{* * *}$ \\
\hline AR2 & -1.608 & -0.739 & -1.163 \\
\hline Hansen test & 5.688 & 22.84 & 19.36 \\
\hline
\end{tabular}

The dependent variable $\mathrm{LEV} 22_{\mathrm{t}}$ is defined as total liabilities and debt to total assets at the end of period $\mathrm{t}$; LEV2 $2_{\mathrm{t}-1}$ : debt ratio at time t-1; MTB: growth opportunities; TANG: tangibility of assets; SIZE: natural logarithm of the total volume of assets; ROA: EBIT/ total assets; NDTS: amortization between total assets; DWR: wage share; MPH: Herfindahl Hirschman index; MPS: market share. Estimated coefficients and p-values $(\mathrm{P}>|\mathrm{z}|)$ in parentheses. The Wald test contrasts the joint significance of the explanatory variables. AR1 and AR2 are first and second order serial correlation statistics. The Hansen test is distributed as a $\chi^{2}$ with degrees of freedom equal to the number of estimated coefficients. ***, **, *: statistical significance at the $1 \%, 5 \%$ and $10 \%$ level.

financial instability and so boost economic growth.

\section{CRediT authorship contribution statement}

Pedro Luis Vega-Gutierrez: Conceptualization, Methodology, Formal analysis, Writing - original draft, Visualization. Félix J. López-Iturriaga: Conceptualization, Writing - review \& editing, Funding acquisition. Juan Antonio Rodriguez-Sanz: Conceptualization, Resources, Writing - review \& editing.

\section{Appendix A. Supplementary data}

Supplementary material related to this article can be found, in the online version, at doi:https://doi.org/10.1016/j.ribaf.2021. 101431.

\section{References}

Aggarwal, R., Kyaw, N., 2006. Transparency and capital structure: evidence of firm, industry, and national institutional influences. In: Oxelheim, L. (Ed.), Corporate and Institutional Transparency for Economic Growth in Europe. Elsevier, Amsterdam, pp. 335-370 chapter 12.

Agrawal, A.K., Matsa, D.A., 2013. Labor unemployment risk and corporate financing decisions. J. Financ. Econ. 108, 449-470. https://doi.org/10.1016/j. jfineco.2012.11.006.

Akerlof, G.A.W., Dickens, W.T., Perry, G.L., Gordon, R.J., Mankiw, N.G., 1996. The macroeconomics of low inflation. Brook. Pap. Econ. Act. Microecon. 27 (1), 1-76. https://www.jstor.org/stable/2534646.

Akyol, A.C., Verwijmeren, P., 2013. Human capital costs, firm leverage, and unemployment rates. J. Financ. Intermediation 22 (3), 464-481. https://doi.org/ 10.1016/j.jfi.2013.04.003.

Antoniou, A., Guney, Y., Paudyal, K., 2008. The determinants of capital structure: capital market-oriented versus bank-oriented institutions. J. Financ. Quant. Anal. 43 (1), 59-92. https://doi.org/10.1017/S0022109000002751.

Ardalan, K., 2017. Capital structure theory: reconsidered. Res. Int. Bus. Financ. 39, 696-710. https://doi.org/10.1016/j.ribaf.2015.11.010.

Arellano, M., Bond, S., 1991. Some tests of specification for panel data: monte Carlo evidence and an application to employment equations. Rev. Econ. Stud. 58, 277-297. https://doi.org/10.2307/2297968. 
Aubert, N., Kern, A., Hollandts, X., 2017. Employee stock ownership and the cost of capital. Res. Int. Bus. Financ. 41, 67-78. https://doi.org/10.1016/j. ribaf.2017.04.007.

Bae, K.-H., Kang, J.-K., Wang, J., 2011. Employee treatment and firm leverage: a test of the stakeholder theory of capital structure. J. financ. econ. 100 (1), 130-153. https://doi.org/10.1016/j.jfineco.2010.10.019.

Barnea, A., Haugen, R.A., Senbet, L.W., 1985. Agency problems and financial contracting. Prentice Hall.

Bastos, D.D., Nakamura, W.T., Basso, L.F.C., 2009. Determinants of capital structure of publicly-traded companies in Latin America: the role of institutional and macroeconomic factors. J. Int. Financ. Econ. 9 (3), 24-39. https://doi.org/10.2139/ssrn.1365987.

Basu, K., 2015. Market imperfections and optimal capital structure: evidence from indian panel data. Glob. Bus. Rev. 16 (1), 61-83. https://doi.org/10.1177/ 0972150914553509.

Baumol, W.J., Panzar, J., Willing, R., 1982. Contestable Markets and the Theory of Industry Structure. Saunders College Publishing/Harcourt Brace.

Becker, G.S., 1965. A theory of the allocation of time. Econ. J. 299 (77), 493-517. https://doi.org/10.1111/ecoj.12157.

Bell, B., Machin, S., 2018. Minimum wages and firm value. J. Labor Econ. 36 (1), 159-195. https://www.jstor.org/stable/2228949.

Ben-Nasr, H., 2019. Do unemployment benefits affect the choice of debt source? J. Corp. Financ. 56, 88-107. https://doi.org/10.1016/j.jcorpfin.2019.01.006.

Berger, A.N., Bonaccorsi di Patti, E., 2006. Capital structure and firm performance: A new approach to testing agency theory and an application to the banking industry. J. Banking Finance 30 (4), 1065-1102. https://doi.org/10.1016/j.jbankfin.2005.05.015.

Bertola, G., Dabusinskas, A., Hoeberichts, M., Izquierdo, M., Kwapil, C., Montornès, J., Radowski, D., 2012. Price, wage and employment response to shocks: evidence from the WDN survey. Labour Econ. 19 (5), 783-791. https://doi.org/10.1016/j.labeco.2012.03.008.

Besanko, D., Dranove, D., Shanley, M., Schaefer, S., 2012. Economics of Strategy. Wiley, New York.

Betcherman, G., 2014. Labor market regulations: what do we know about their impacts in developing countries? World Bank Res. Obs. 30 (1), 124-153. https://doi. org/10.1093/wbro/lku005.

Blanchard, O., 2017. Macroeconomía. Pearson, Madrid.

Blanchard, O., Giavazzi, F., 2003. Macroeconomic effects of regulation and deregulation in goods and labor markets. Q. J. Econ. 188, 879-907. https://doi.org/ 10.1162/00335530360698450.

Blundell, R., Bond, S., 1998. Initial conditions and moment restrictions in dynamic panel data models. J. Econom. 87 (1), 115-143. https://doi.org/10.1016/S03044076(98)00009-8.

Boeri, T., 2011. Institutional reforms and dualism in European labor markets. Handbook of labor economics. In: Ashenfelter, O., Card, D. (Eds.), Handbook of Labor Economics, 1 ed., vol. 4. Elsevier, Amsterdam, pp. 1173-1236. chapter 13.

Botero, J.C., Djankov, S., La Porta, R.F., Lopez De-Silanes, F., Shleifer, A., 2004. The regulation of labor. Q. J. Econ. 119, 1339-1382. https://doi.org/10.1162/ 0033553042476215.

Brown, J., Matsa, D.A., 2016. Boarding a sinking ship? An investigation of job applications to distressed firms. J. Finance 71 (2), 507-550. https://doi.org/10.1111/ jofi.12367.

Camara, O., 2012. Capital structure adjustment speed and macroeconomic conditions: U.S. MNCs and DCs. Int. Res. J. Finance and Econ. 84, 106-120. https://doi. org/10.1016/j.mulfin.2012.10.001.

Chang, X., Chen, Y., Dasgupta, S., 2019. Macroeconomic conditions, financial constraints, and companies financing decisions. J. Bank. Financ. 101, 242-255. https:// doi.org/10.1016/j.jbankfin.2018.10.016.

Chen, M., Matousek, R., 2020. Do productive firms get external finance? Evidence from Chinese listed manufacturing firms. Int. Rev. Financ. Anal. https://doi.org/ 10.1016/j.irfa.2019.101422.

Cook, D., Tang, T., 2010. Macroeconomic conditions and capital structure adjustment speed. J. Corp. Financ. 16 (1), 73-87. https://doi.org/10.1016/j. jcorpfin.2009.02.003.

Daskalakis, N., Balios, D., Dalla, V., 2017. The behaviour of SMEs' capital structure determinants in different macroeconomic states. J. Corp. Financ. 246, 248-260. https://doi.org/10.1016/j.jcorpfin.2017.07.005.

De Miguel, A., Pindado, J., 2001. Determinants of the capital structure: new evidence from Spanish data. J. Corp. Financ. 7, 77-99. https://doi.org/10.1016/S09291199(00)00020-1.

DeAngelo, H., Masulis, R.W., 1980. Leverage and dividend irrelevancy under corporate and personal taxation. J. Finance 35 (2), $453-464$. https://www.jstor.org/ stable/2327405.

Dickens, W.T., Goette, L., Groshen, E.L., Holden, S., Messina, J., et al., 2007. How wages change: micro evidence from the International Wage Flexibility Project. J. Econ. Perspect. 21 (2), 195-214. https://doi.org/10.1257/jep.21.2.195.

Drobetz, W., Schilling, D.C., Schröder, H., 2015. Heterogeneity in the speed of capital structure adjustment across countries and over the business cycle. Eur. Financ. Manag. 21 (5), 936-973. https://doi.org/10.1111/eufm.12048.

Dugan, M.T., Minyard, D.H., Shriver, K.A., 1994. A Re-Examination of the operating leverage-financial leverage tradeoff hypothesis. Q. Rev. Econ. Financ. 34 (3), 327-334. https://EconPapers.repec.org/RePEc:eee:quaeco:v:34:y:1994:i:3:p:327-334.

Ellul, A., Pagano, M., 2019. Corporate leverage and employees' rights in bankruptcy. J. Financ. Econ. 133 (3), 685-707. https://doi.org/10.1016/j. jfineco.2019.05.002.

Elsby, M., 2009. Evaluating the economic significance of downward nominal wage rigidity. J. Monet. Econ. 56 (2), 154-169. https://doi.org/10.1016/j. jmoneco.2008.12.003.

Falato, A., Liang, N., 2015. Do creditor rights increase employment risk? Evidence from loan covenants. J. Finance 71 (6), 2545-2590. https://doi.org/10.1111/ jofi. 12435.

Fama, E., French, K., 2002. Testing tradeoff and pecking order predictions about dividends and debt. Rev. Financ. Stud. 15, 1-33. https://doi.org/10.1093/rfs/15.1.1.

Flannery, M., Rangan, K., 2006. Partial adjustment toward target capital structures. J. Financ. Econ. 79, 469-506. https://doi.org/10.1016/j.jfineco.2005.03.004.

Frank, M.Z., Goyal, V.K., 2009. Capital structure decisions: which factors are reliably important? Financ. Manage. 38 (1), 1-37. https://doi.org/10.1111/j.1755053X.2009.01026.x.

Funke, M., Maurer, W., Strulik, H., 1999. Capital structure and labour demand: investigations using german Micro data. Oxf. Bull. Econ. Stat. 61 (2), 199-215. https:// doi.org/10.1111/1468-0084.00125.

Gonzalez, V.M., González, F., 2008. Influence of bank concentration and institutions on capital structure: new international evidence. J. Corp. Financ. 14 (4), 363-375. https://doi.org/10.1016/j.jcorpfin.2008.03.010.

Graham, J.R., Kim, H., Li, S., Qiu, J., 2016. Employee Costs of Corporate Bankruptcy. Working Paper. Duke University, Durham, NC.

Gustafson, M., Kotter, J.D., 2018. Minimum Wage and Corporate Policy. Work. Pap. Pa. State Univ., State College.

Habib, A., Costa, M.D., Huang, H.J., Bhuiyan, M.B.U., Sun, L., 2020. Determinants and consequences of financial distress: review of the empirical literature. Account. Financ. 60, 1023-1075. https://doi.org/10.1111/acfi.12400.

Halling, M., Yu, J., Zechner, J., 2016. Leverage dynamics over the business cycle. J. Financ. Econ. 122 (1), 21-41. https://doi.org/10.1016/j.jfineco.2016.07.001.

Hanka, G., 1998. Debt and the terms of employment. J. Financ. Econ. 48, 245-282. https://doi.org/10.1016/S0304-405X(98)00012-9.

Hanousek, J., Shamshur, A., 2011. A stubborn persistence: is the stability of leverage ratios determined by the stability of the economy? J. Corp. Financ. 17 (5), 1360-1376. https://doi.org/10.1016/j.jcorpfin.2011.07.004.

Hayter, S., 2011. The Role of Collective Bargaining in the Global Economy: Negotiating for Social Justice. Edward Elgar Publishing, Northampton.

Hennessy, C.A., Livdan, D., 2009. Debt, bargaining, and credibility in firm-supplier relationships. J. Financ. Econ. 93 (3), 382-399. https://doi.org/10.1016/j. jfineco.2008.05.006.

Hovakimian, A., Opler, T., Titman, S., 2001. The debt-equity choice: an analysis of issuing companies. J. Financ. Quant. Anal. 36, 1-24. https://doi.org/10.2307/ 2676195. 
Huong, P.T.Q., 2018. Macroeconomic factors and corporate capital structure: evidence from listed joint stock companies in Vietnam. Int. J. Financ. Res. 9 (1), 31-40. https://doi.org/10.5430/ijfr.v9n1p31.

Jayadev, A., 2007. Capital account openness and the labour share of income. Cambridge J. Econ. 31, 423-443. https://doi.org/10.1093/cje/bel037.

Jensen, M.C., 1986. Agency costs of free cash flow, corporate finance and takeovers. Am. Econ. Rev. 76 (2), 323-329. https://www.jstor.org/stable/1818789.

Jensen, M.C., Meckling, W., 1976. Theory of the firm: managerial behaviour, agency cost and ownership structure. J. Financ. Econ. 3 (4), 305-360. https://doi.org/ 10.1016/0304-405X(76)90026-X.

Kahl, M., Lunn, J., Nilsson, M., 2014. Operating Leverage and Corporate Financial Policies. Working Paper. University of Colorado.

Kayhan, A., Titman, S., 2007. Companies' histories and their capital structure. J. Financ. Econ. 83, 1-32. https://doi.org/10.1016/j.jfineco.2005.10.007.

Keynes, J., 1936. The General Theory of Employment, Interest and Money. Macmillan Cambridge University Press, Cambridge.

Kuzmina, O., 2013. Operating flexibility and capital structure: evidence from a natural experiment. Columbia Business School Res. Paper 13-69.

Lallement, M., 2011. Europe and the economic crisis: forms of labour market adjustment and varieties of capitalism. Work. Employ. Soc. 25 (4), 627-641. https://doi. org/10.1177/0950017011419717.

Lindbeck, A., Snower, D., 1988. The Insider-Outsider Theory of Employment and Unemployment. MIT Press, Cambridge, MA.

MacKay, P., 2003. Real flexibility and financial structure: an empirical analysis. Rev. Financ. Stud. 16 (4), 1131-1165. https://doi.org/10.1093/rfs/hhg022.

Mankiw, N.G., Reis, R., 2006. Pervasive stickiness. Am. Econ. Rev. 96 (2), 164-169. https://doi.org/10.1257/000282806777211937.

Mao, C.X., 2003. Interaction of debt agency problems and optimal capital structure: theory and evidence. J. Financ. Quant. Anal. 38 (2), 399-423. https://doi.org/ $10.2307 / 4126757$.

Matsa, D.A., 2010. Capital structure as a strategic variable: evidence from collective bargaining. J. Finance 65, 1197-1232. https://doi.org/10.1111/j.15406261.2010.01565.x.

Matsa, D.A., 2018. Capital structure and a firm's workforce. Annu. Rev. Financ. Econ. 10, 387-412. https://doi.org/10.1146/annurev-financial-110716-032519.

Mauer, D.C., Triantis, A.J., 1994. Interactions of corporate financing and investment decisions: a dynamic framework. J. Finance 49 (4), 1253-1277. https://doi.org/ 10.1111/j.1540-6261.1994.tb02453.x.

Mishkin, F.S., 2016. The Economics of Money, Banking, and Financial Markets. Pearson, London.

Mokhova, N., Zinecker, M., 2014. Macroeconomic factors and corporate capital structure. Procedia Soc. Behav. Sci. 110, 530-540. https://doi.org/10.1016/j. sbspro.2013.12.897.

Morandi, A., Paulet, E., 2019. The firm-specific determinants of capital structure - an empirical analysis of firms before and during the Euro Crisis. Res. Int. Bus. Financ. 47, 150-161. https://doi.org/10.1016/j.ribaf.2018.07.007.

Myers, S.C., 1977. Determinants of corporate borrowing. Journal of Financial Economics 5, 147-175. https://doi.org/10.1016/0304-405X(77)90015-0.

Myers, S.C., Majluf, N.S., 1984. Corporate financing and investment decisions when companies have information that investors do not have. J. Financ. Econ. 13 (2), 187-221. https://doi.org/10.1016/0304-405X(84)90023-0.

Olivera, J., 1964. On structural inflation and latin-american 'Structuralism'. Oxf. Econ. Pap. 16, 321-332. https://www.jstor.org/stable/2662572.

Onaran, Ö., 2009. Wage share, globalization, and crisis: the case of manufacturing industry in Korea, Mexico, and Turkey. Int. Rev. Appl. Econ. 23, 113-134. https:// doi.org/10.1080/02692170802700435.

Park, S., Shin, D., 2019. Inflation and wage rigidity/flexibility in the short run. Econ. Inq. 57 (3), 1675-1697. https://doi.org/10.1111/ecin.12786.

Phillips, A.W.H., 1958. The relation between unemployment and the rate of change of money wage rates in the United Kingdom. Economica 25 (100), $1861-1957$. https://doi.org/10.1111/j.1468-0335.1958.tb00003.x.

Rajan, R.G., Zingales, L., 1995. What do we know about capital structure? Some evidence from international data. J. Finance 1, 1421-1461. https://doi.org/10.1111/ j.1540-6261.1995.tb05184.x.

Schoefer, B., 2015. The Financial Channel of Wage Rigidity. PhD Thesis. Harvard University, Cambridge, MA.

Serfling, M.A., 2013. Labor Adjustment Costs and Capital Structure Decisions. Working Paper. Financial Management Association Annual Meeting and workshop at the University of Arizona.

Serfling, M.A., 2016. Firing costs and capital structure decisions. J. Finance 71 (5), 2239-2286. https://doi.org/10.1111/jofi.12403.

Shapiro, C., Stiglitz, J.E., 1984. Equilibrium unemployment as a worker discipline device. Am. Econ. Rev. 74 (3), $433-444$. https://www.jstor.org/stable/1804018.

Sharpe, S.A., 1994. Financial market imperfections, firm leverage, and the cyclicality of employment. Am. Econ. Rev. 84, 1060-1074. https://www.jstor.org/stable/ 2118044.

Shyam-Sunder, L., Myers, S.C., 1999. Testing Static Tradeoff against Pecking Order Models of Capital Structure. J. Financ. Econ. 51, 219-244. https://doi.org/ 10.1016/S0304-405X(98)00051-8.

Simintzi, E., Vig, V., Volpin, P., 2015. Labor protection and leverage. Rev. Financ. Stud. 28 (2), 561-591. https://doi.org/10.1093/rfs/hhu053.

Škulánová, N., 2019. Influence of selected determinants on the financial structure in the civil engineering companies in the selected countries. Soc. Tyrim. 42 (2), 5-15. https://doi.org/10.21277/st.v42i2.268.

Stockhammer, E., 2017. Determinants of the wage share: a panel analysis of advanced and developing economies. Br. J. Ind. Relat. 55 (1), 3-33. https://doi.org/ $10.1111 /$ bjir.12165.

Stoft, S., 2002. Power System Economics: Designing Markets for Electricity. Wiley-IEEE Press, New York.

Stulz, R., 1990. Managerial discretion and optimal financing policies. J. Financ. Econ. 26 (1), 3-27. https://doi.org/10.1016/0304-405X(90)90011-N.

Suzuki, K., Zushi, N., 2020. Labour unions and leverage: evidence from firm-level union data. Appl. Econ. 52 (27), 2882-2894. https://doi.org/10.1080/ 00036846.2019 .1683150 .

Titman, S., 1984. The effect of capital structure on a firm's liquidation decision. J. Financ. Econ. 13, 137-151. https://doi.org/10.1016/0304-405X(84)90035-7.

Titman, S., Wessels, R., 1988. The determinants of capital structure choice. J. Finance 43, 1-18. https://doi.org/10.1111/j.1540-6261.1988.tb02585.x.

Tobin, J., 1972. Inflation and unemployment. Am. Econ. Rev. 62 (1), 1-18.

Woods, K., Tan, K.J.K., Faff, R., 2019. Labor unions and corporate financial leverage: the bargaining device versus crowding-out hypotheses. J. Financ. Intermediation 37, 28-44. https://doi.org/10.1016/j.jfi.2017.05.005.

Zhou, Q., Jui Keng Tan, K., Faff, R., Zhu, Y., 2016. Deviation from target capital structure, cost of equity and speed of adjustment. J. Corp. Financ. 39, 99-120. https:// doi.org/10.1016/j.jcorpfin.2016.06.002. 